\title{
Effect of insulin concentration, subcutaneous fat thickness and skin temperature on subcutaneous insulin absorption in healthy subjects
}

\author{
G. Sindelka, L.Heinemann, M. Berger, W. Frenck, E. Chantelau \\ Department of Nutrition and Metabolism, WHO Collaborating Center for Diabetes, Heinrich-Heine-University of Düsseldorf, \\ Düsseldorf, Germany
}

\begin{abstract}
Summary Subcutaneous insulin absorption kinetics were assessed in 50 healthy study subjects ( 21 female, 29 male; age $26 \pm 3$ years, BMI $22.5 \pm 1.8 \mathrm{~kg} / \mathrm{m}^{2}$; mean $\pm \mathrm{SD}$ ) during $45 \mathrm{~min}$ after periumbilical injection of soluble human U40- or U100-insulin $(0.15 \mathrm{IU} / \mathrm{kg})$. Subcutaneous fat thickness was measured by ultrasound, and skin temperature at the injection site was registered. Serum insulin concentrations increased within $30 \mathrm{~min}$ from basal values of $37 \pm 15$ to $140 \pm 46 \mathrm{pmol} / \mathrm{l}$ after U40-insulin and from $36 \pm 10$ to $116 \pm 37 \mathrm{pmol} / 1$ after U100-insulin $(p<0.001)$. After 45 min serum insulin concentrations were $164 \pm 43 \mathrm{pmol} / \mathrm{l}$ with $\mathrm{U} 40$-insulin and $128 \pm 35 \mathrm{pmol} / 1$ with U100-insulin $(p<0.001)$. Decline in blood glucose levels and suppression of C-
\end{abstract}

peptide were comparable. The serum insulin levels reached 30 and 45 min after U40- and U100-insulin injection were positively correlated with skin temperature $(p<0.0008)$, and negatively correlated with subcutaneous fat thickness $(p<0.009)$. In conclusion, the lower insulin concentration of U40-insulin, higher skin temperature, and a thinner subcutaneous fat tissue at the injection site are associated with accelerated and enhanced subcutaneous insulin absorption. [Diabetologia (1994) 37: 377-380]

Key words Diabetes mellitus, pharmacokinetics, insulin absorption, metabolic control, skin temperature.
Considering the importance of a rapid increase of the serum insulin level to avoid excessive meal-related blood glucose excursions, rapid absorption of soluble insulin is required, especially for intensified insulin therapies. To accelerate the absorption of insulin, massage and heating of the injection site have each been used successfully $[1,2]$. However, the absorption of subcutaneously administered soluble insulin is dependent on a number of patient variables, such as body mass index and subcutaneous fat thickness [3], and insulin characteristics (e.g. insulin species and concentration $[4,5])$. When differences in insulin concentrations were substantial, i.e. between 10 and

Received: 5 August 1993

and in revised form: 21 October 1993

Corresponding author: Professor E. Chantelau, Department of Nutrition and Metabolism, Heinrich-Heine-University Düsseldorf, P.O.Box 1010 07, Moorenstrasse 5, D-40001 Düsseldorf, Germany
$5000 \mathrm{IU} / \mathrm{ml}$ [5] slower absorption of more concentrated insulin was most clearly demonstrated. Reports concerning differences in pharmacokinetic properties between $40 \mathrm{IU} / \mathrm{ml}$ insulin (U40) and $100 \mathrm{IU} / \mathrm{ml}$ (U100) have been inconsistent, mainly due to small sample sizes [6-8]. The following study assesses the impact of a 2.5-fold increase from U40- to U100-insulin on insulin absorption from the subcutaneous depot, as well as confounding anthropometric variables in a large sample of healthy subjects.

\section{Subjects, materials and methods}

\section{Subjects}

The study group comprised 21 female and 29 male healthy volunteers (age $26 \pm 3$ (range 17-32) years; BMI $22.5 \pm 1.8$ (range $19.6-27.5) \mathrm{kg} / \mathrm{m}^{2}$ ). They had no family history of diabetes and were not taking any medication (except oral contraceptives) during the study. The study was carried out according to the prin- 

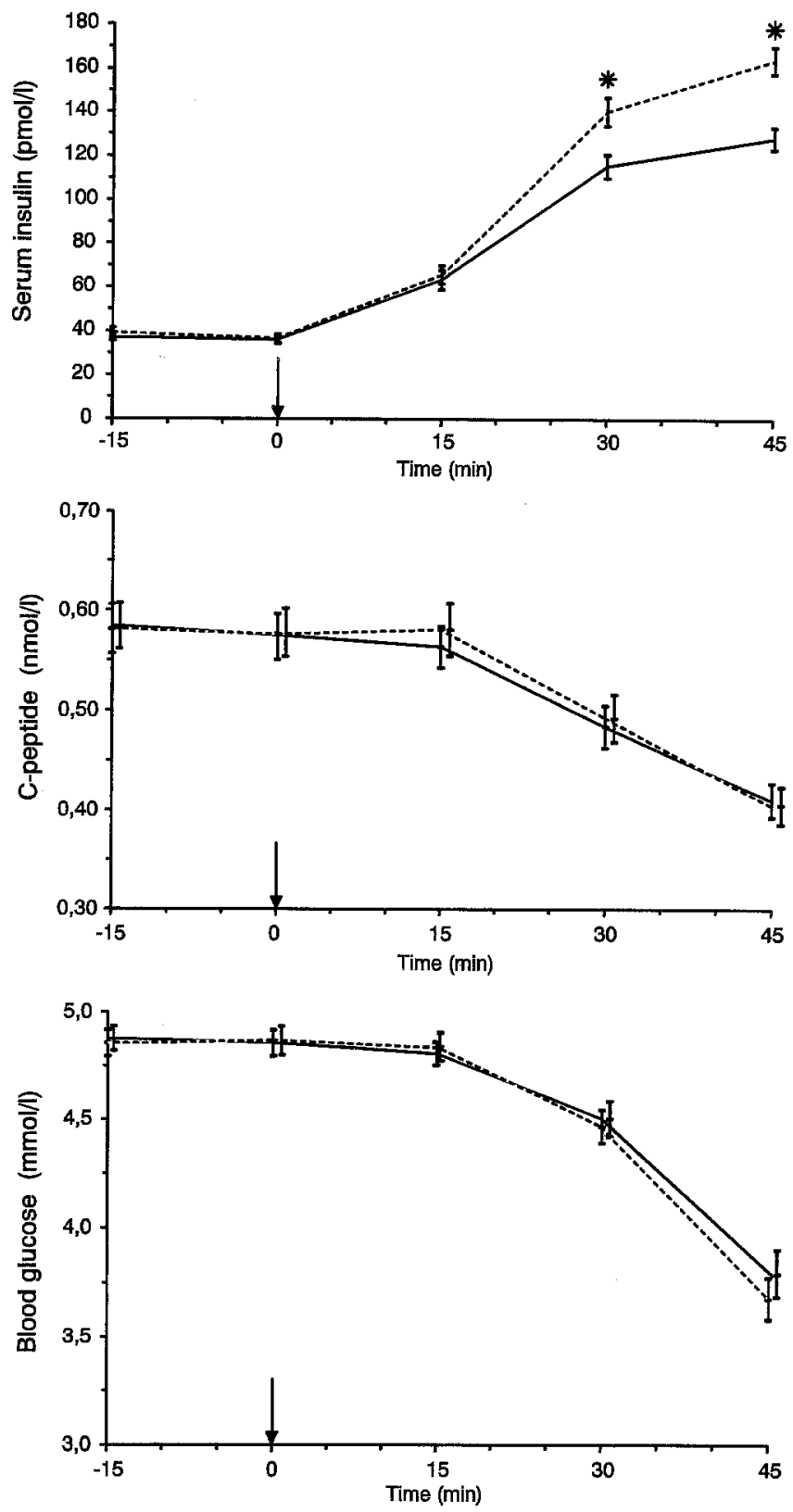

Fig. 1. Serum insulin, C-peptide and blood glucose concentration after subcutaneous injection of $\mathrm{U} 40$-insulin (---; mean \pm SEM) or U100-insulin (-). Asterisks mark significantly different serum insulin concentrations $(* p<0.001)$

ciples of the Declaration of Helsinki and was approved by the local ethical committee. Informed consent was obtained from all subjects prior to participation.

\section{Study design}

After an overnight fast the subjects were brought to the test room and placed in a comfortable arm chair throughout the experiment. They had been asked to abstain from alcohol, coffee, smoking, and strenuous physical exercise for at least $12 \mathrm{~h}$ prior to the study.

After acclimatisation for $30 \mathrm{~min}$, a cannula (length $22.2 \mathrm{~mm}$; diameter $1.1 \mathrm{~mm}$; Abbott, Wiesbaden, Germany) was inserted into an antecubital vein and kept patent with an infusion of $0.9 \%$ $\mathrm{NaCl}$. A basal blood sample was drawn 15 min prior to the injection of insulin. At time 0, human soluble insulin (Actrapid HM; Novo Nordisk, Mainz, Germany) at a dose of $0.15 \mathrm{IU} / \mathrm{kg}$ was injected strictly subcutaneously into a marked skin fold of the abdominal region ( $3 \mathrm{~cm}$ horizontal to the umbilicus) with a syringe (Micro Fine low dose IV +, needle length $13 \mathrm{~mm}$; Becton-Dickinson, Heidelberg, Germany). Additional blood samples were drawn at 15, 30, $45 \mathrm{~min}$, after which the experiment was ended. To prevent symptomatic hypoglycaemia the volunteers were then given a glucose rich drink and meal. On two separate study days within one week, U40- or U100-insulin were given in randomised order. The temperature in the test room was $22-24^{\circ} \mathrm{C}$, and the subjects were dressed accordingly.

Skin temperature at the insulin injection site was measured with a calibrated hand-held thermometer (Sekundenthermometer 1100; Testoterm, Lenzkirch, Germany; accuracy $\pm 0.2^{\circ} \mathrm{C}$ ) each time blood samples were drawn. On the first test day only, thickness of the subcutaneous fat layer in the area of the injection site was estimated by ultrasonography (B-Mode, Picker L-S 5000; Espelkamp, Germany; $7.5 \mathrm{Mhz}$ ), and body weight in light clothing was measured by use of an electronic hospital balance.

\section{Analyticalmethods}

Serum insulin concentration and C-peptide concentrations were measured by commercially available RIAs (Pharmacia Insulin RIA 100, Uppsala, Sweden; RIAgnost HC-Peptid, Behring Werke, Marburg, Germany). The inter-assay coefficient of variation of the insulin assay was $10.3 \%$ at $24 \mathrm{pmol} / 1$ and $5.1 \%$ at $180 \mathrm{pmol} / \mathrm{l}$. The inter-assay coefficient of variation of the C-peptide assay was $6.4 \%$ at $0.5 \mathrm{nmol} / \mathrm{l}$. Plasma glucose concentrations were measured by the glucose oxidase method (Glucose Analyzer II; Beckman Instruments, Fullerton, Calif., USA).

\section{Statistical analysis}

Results are given as mean \pm SD. Standard parametric statistical analysis methods ( $t$-test, linear and stepwise multiple regression analysis) were used after testing the results for normal distribution. Differences in the serum insulin concentration profiles on the first and second test day were analysed by analysis of variance for repeated measurements (PROC GLM, Statistical Analysis System; SAS Institute, Raleigh, NC, USA).

\section{Results}

\section{Serum insulin levels}

At 30 min after subcutaneous injection serum insulin levels increased with both insulin concentrations (Fig. 1). However, the increase from basal values (U40insulin $37 \pm 15 \mathrm{pmol} / 1, \mathrm{U} 100$-insulin $36 \pm 10 \mathrm{pmol} / 1)$ was significantly more rapid with $\mathrm{U} 40$-insulin at $30 \mathrm{~min}$ $(140 \pm 46 \mathrm{pmol} / \mathrm{l})$ and $45 \mathrm{~min}(164 \pm 42 \mathrm{pmol} / \mathrm{l}) \mathrm{com}-$ pared to U100-insulin $(116 \pm 37$ and $128 \pm 35 \mathrm{pmol} / \mathrm{l}$; analysis of variance $p<0.0001)$. The differences between the serum insulin levels achieved 30 and $45 \mathrm{~min}$ after injection of U40-insulin and U100-insulin were 
$25 \pm 39$ and $37 \pm 30 \mathrm{pmol} / 1$, respectively. The frequency distribution of the serum insulin differences at 30 and 45 min resembles a Gaussian distribution with one maximum (NS; Kolmogorov-Smirnow-test). Serum insulin levels $30 \mathrm{~min}$ after subcutaneous injection of U40insulin were higher in 37 subjects, lower in 11 , and equal in one subject compared with U100-insulin. After $45 \mathrm{~min}$ they were higher in 41 and lower in 7 subjects.

\section{Blood glucose}

The decrease in blood glucose levels from basal values (U40-insulin $4.9 \pm 0.5 \mathrm{mmol} / \mathrm{l}$, U100-insulin $4.9 \pm$ $0.4 \mathrm{mmol} / \mathrm{l})$ started $30 \mathrm{~min}$ after insulin injection. A similar decrease of $1.2 \pm 0.5$ (U40-insulin) and $1.2 \pm 0.6$ (U100-insulin) $\mathrm{mmol} / \mathrm{l}$ resulted in blood glucose values of $3.7 \pm 0.7$ and $3.8 \pm 0.8 \mathrm{mmol} / 1$, respectively after 45 min (Fig. 1).

\section{C-peptide}

Suppression of endogenous insulin production, as indicated by decreasing C-peptide concentrations, was detected 30 min after insulin injection. At 45 min C-peptide concentrations were the same with both insulin concentrations injected (U40-insulin $71 \pm 24 \%$ vs U100-insulin $70 \pm 23 \%$ of baseline values; Fig. 1).

\section{Skin temperature and fat thickness}

At $30 \mathrm{~min}$ and $45 \mathrm{~min}$, similar correlations for serum insulin, skin temperature and fat thickness were obtained. Therefore, only the results at $45 \mathrm{~min}$ are presented. Skin temperature was not significantly different on both test days, correlating significantly with serum insulin levels $45 \mathrm{~min}$ after injection of U40insulin and U100-insulin (U40-insulin: $r=0.55, p=$ 0.0001; U100-insulin: $r=0.47, p=0.0008$ ) (Fig. 2). The fat layer thickness of the 50 study subjects was $6 \pm 2 \mathrm{~mm}$ (range $2-10 \mathrm{~mm}$ ); it was negatively correlated with serum insulin concentrations $45 \mathrm{~min}$ after U40- $(r=$ $-0.40 ; p=0.004)$ and U100-insulin $(r=-0.38 ; p=$ $0.009)$ injection.

\section{Analysis of variance}

Stepwise regression analysis for the U40 and U100 experiments revealed that fat tissue thickness and skin temperature accounted for $47 \%$ (U40) and $36.5 \%$ (U100) of the variance in serum insulin concentration at $45 \mathrm{~min}$. The influence of the insulin dose was negligible ( $<0.1 \%$ of variance) with both insulin concentrations.
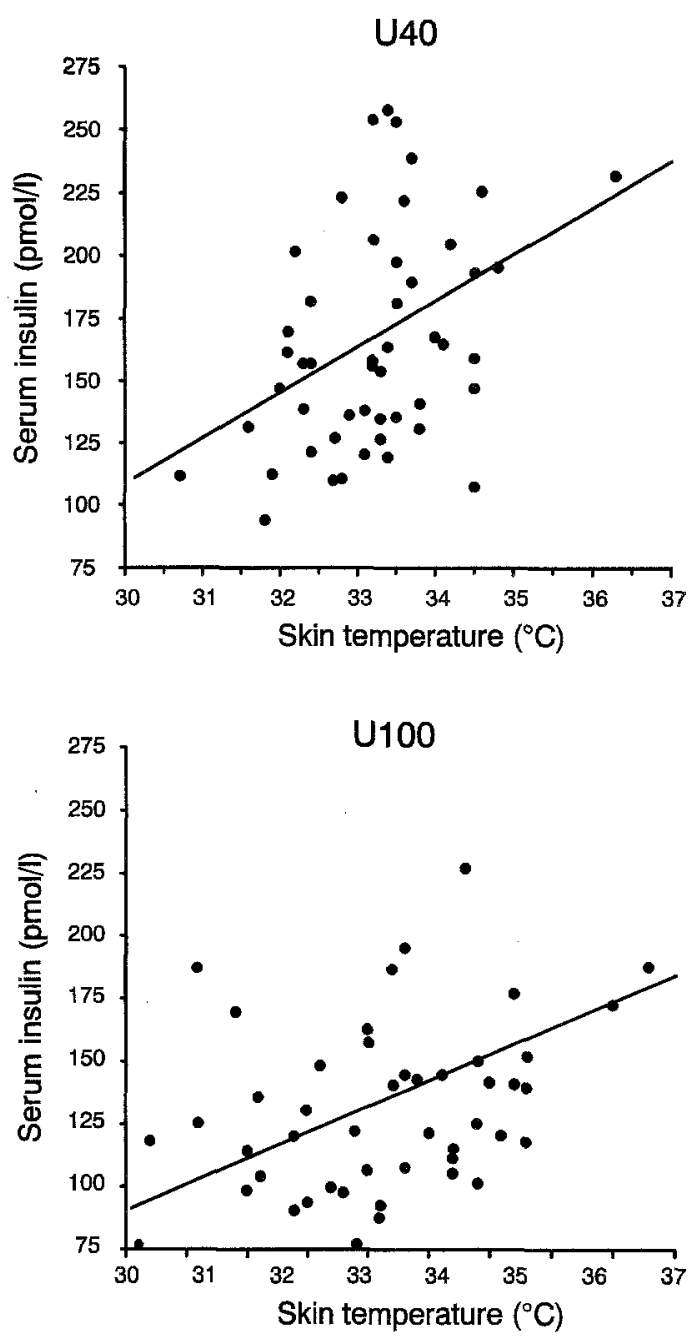

Fig. 2. Correlation between skin temperature at the injection site and serum insulin concentration $45 \mathrm{~min}$ after insulin injection (U40-insulin: $y=3.05 x-73.8, r=0.55, p=0.0001$; U100-insulin: $y=2.12 x-48.7, r=0.47, p=0.0008$ )

\section{Discussion}

Subcutaneous administration of soluble U40- or U100insulin resulted in $20 \%$ higher serum insulin concentrations 30 and $45 \mathrm{~min}$ after injection of U40-insulin. Suppression of endogenous insulin production and decrease in blood glucose from basal values were not significantly different after U40- or U100-insulin administration, as has been observed in other studies on insulin absorption in healthy subjects $[1,4]$.

Absorption of exogenous insulin from the subcutaneous tissue is influenced by a series of factors: insulin type, species, dose, concentration, injection site and depth, physical activity, heating and cooling of the injection site, local blood flow, and metabolic state [1-5, 9]. Rate limiting factors for absorption of subcutaneously injected insulin may be dissolution in the interstitial fluid, interstitial transport to the capillary by diffusion and percolative transport, capillary membrane transport, and tissue blood flow [10]. 
The more rapid absorption of the lower concentrated U40-insulin preparation compared to the 2.5 times more concentrated U100-insulin may be explained by the greater surface area of the respective insulin bolus, and the greater number of tissue capillaries to which the injected insulin is exposed. On the other hand, capillary diffusion capacity is dependent on the degree of insulin polymerisation. Whereas insulin monomers and dimers can be absorbed rapidly, the larger insulin hexamers - to which insulin molecules self-associate in pharmaceutical insulin preparations are absorbed at much lower rates [11]. The proportion of insulin hexamers in the injected insulin preparation is claimed to be higher with U100-insulin than with U40-insulin [11]. Thus, the time needed for the dissociation of the hexamers into dimers or monomers by dilution of the injected insulin within the subcutaneous tissue should be longer for U100-insulin than with U40insulin, resulting in lower absorption rates of U100-insulin in the time immediately after injection [11].

Previous studies have shown that exogenous variation of skin temperature has a profound influence on insulin absorption $[1,2,10,12]$, possibly by acceleration of the subcutaneous insulin dissociation [2]. However, in these studies skin temperature was either raised or lowered drastically. To evaluate whether individual differences in endogenous skin temperature at normal ambient room temperature have an influence on insulin absorption, we estimated the local skin temperature at the injection site throughout the study period (while maintaining nearly constant room temperature). The skin temperatures at $45 \mathrm{~min}$ registered after either U40- or U100-insulin administration showed a significant correlation with the serum insulin concentrations attained after U40- and U100-insulin injection, respectively. This demonstrates for the first time that individual body temperature at the injection site is one of the determinants of individual subcutaneous insulin absorption patterns. Consistent with previous reports on disappearance of radiolabelled insulin $[3,13]$, in our study using the direct method of monitoring insulin appearance $[1,13]$, insulin absorption was negatively correlated with subcutaneous fat tissue thickness. The insulin dose given per $\mathrm{kg}$ body weight in this study had no effect on the rate of absorption.

In conclusion, we have shown in healthy study subjects that soluble U40-insulin is absorbed significantly faster from the subcutaneous tissue than U100-insulin. Furthermore, insulin absorption from the subcutaneous tissue at 30 and 45 min after injection was significantly correlated to the local skin temperature and subcutaneous fat thickness. The impact of these findings for insulin treatment as well as for pharmacokinetic studies of subcutaneous insulin absorption properties remains to be elucidated.
Acknowledgements. The help of Dr. R. Bender with the statistical analysis is gratefully acknowledged. This study was supported by the Peter-Klöckner-Foundation, Duisburg, Germany. G.S. was supported by a DAAD grant.

\section{References}

1. Berger M, Cüppers HJ, Hegner H, Jörgens V, Berchtold P (1982) Absorption kinetics and biologic effects of subcutaneously injected insulin preparations. Diabetes Care 2:77-91

2. Thow JC, Johnson AB, Antsiferov M, Home PD (1989) Effect of raising injection-site skin temperature on isophane (NPH) insulin crystal dissociation. Diabetes Care 6: 432-434

3. Vora JP, Burch A, Peters JR, Owens D (1992) Relationship between absorption of radiolabeled soluble insulin, subcutaneous blood flow, and anthropometry. Diabetes Care 11: 1484-1493

4. Waldhäusl WK, Bratusch-Marrain PR, Vierhapper H, Nowotny $\mathbf{P}$ (1983) Insulin pharmacokinetics following continuous infusion and bolus injection of regular porcine and human insulin in healthy man. Metabolism 32: 478-486

5. Galloway JA, Spradlin CT, Nelson RL, Wentworth SM, Davidson JA, Swarner JL (1981) Factors influencing the absorption, serum insulin concentration, and blood glucose responses after injections of regular insulin and various insulin mixtures. Diabetes Care 4: 366-376

6. Lauritzen T, Thorsteinsson B, Pramming S, Sorensen L, Binder C (1984) Subcutaneous absorption of U-40 and U-100 insulin. Horm Metab Res 16: 611-612

7. Heinemann L, Chantelau EA, Starke AAR (1992) Pharmacokinetics and pharmacodynamics of subcutaneously administered U40 and U100 formulations of regular human insulin. Diabete Metab 18: 21-24

8. Hübinger A, Weber W, Jung W, Wehmeyer R, Gries FA (1992) The pharmacokinetics of two different concentrations of short-acting, intermediate-acting and an insulin mixture following subcutaneous injection. Clin Invest 70: 621-626

9. Hildebrandt P (1991) Subcutaneous absorption of insulin in insulin-dependent diabetic patients. Dan Med Bull 38: $337-$ 346

10. Koivisto VA, Fortney S, Hendler R, Felig P (1981) A rise in ambient temperature augments insulin absorption in diabetic patients. Metabolism 4: 402-405

11. Kang S, Brange J, Burch A, Volund A, Owens DR (1991) Subcutaneous insulin absorption explained by insulin's physicochemical properties. Diabetes Care 11: 942-948

12. Rönnemaa T, Koivisto VA (1988) Combined effect of exercise and ambient temperature on insulin absorption and postprandial glycemia in type I patients. Diabetes Care 11: 769-773

13. Heding LG, Ribel U (1986) Pharmacokinetics of subcutaneously administered insulin. In: Serrano-Rios M, Lefebvre PJ (eds), Diabetes 1985. Elsevier, Amsterdam, pp 857-861 